\title{
The Development of the Basic Approaches to Teaching Writing
}

\author{
Zori Barseghyan \\ Yerevan Bryusov State University of Languages and Social Sciences
}

\begin{abstract}
The variety of methodological approaches can contribute to developing the optimal model of teaching writing in higher linguistic universities since implementing only one approach in writing process is unfruitful. However, the priority of this or that approach does not suggest abandoning the other approaches to writing, but puts forward the demand for complementing one another rather than opposing. The content and functional analyses of the product-based, the process-based and the genre-based approaches can lead to paradigm shifts in foreign language teaching/learning methodology, emphasize the importance of the recursive procedure of writing, reveal the main characteristics of writing activities, determine the roles of teachers and students in the process of writing, and develop new strategies teaching writing. Thus a synthesis of the product, the process and the genre approaches to writing will be the best approach to meet the needs of our ESL students.
\end{abstract}

Key words: product-based approach, process-based approach, genre-based approach, cohesive device, learner-centered methodology.

\section{Introduction}

The teaching of writing or writing instruction has always been a compulsory course in higher educational establishments.

Accordingly, there have been various approaches to the teaching of writing that have led to numerous changes in the selection of writing methods and devices. However, in the last years, there has been much debate on the differences of the best of three approaches, namely, the product-based, the process-based and the genre-based approaches. Such debates often generated conflicting views on teaching writing which resulted in paradigm shifts in this sphere. There have basically been two approaches to writing. One approach considers writing as a process. While the product-based writing is a traditional approach, the process-based is a modern one (Flower and Hayes 1981:365-387). In recent years, however, there has been emphasis on the genre-based approach which views writing as a product of social content. 


\section{Content and Functional Characteristics \\ of the Main Approaches to Teaching Writing}

The product approach was used in order to highlight form and syntax and the emphasis was on rhetorical drills (Silva 1990). That is, this approach focuses on linguistic knowledge with the appropriate use of vocabulary, syntax and cohesive devices. In short, writing is viewed as mainly concerned with the knowledge about the structure of language, and writing development is mainly the result of imitation of input, in the form of texts provided by the teacher (Badger and White 2000:153). It is therefore teacher-centered, as the teacher becomes the arbiter of the models used. However there is a debate whether product-based approach is beneficial for the language learners or not. For example, as Prodromou (1995:1-25) states, this approach devalues the learner's potential, both linguistic and personal. Hence this disputable point has led to a paradigm shift, viewing writing as a process. Although there are many different process approaches to writing, they share some core features. Tribble (1996:37) suggests that process approaches stress "[...] writing activities, which move learners from generation of ideas and the collection of data to the 'publication' of a finished text." The process approaches focus on how a text is written, instead of the final outcome. In the process of writing there is much less emphasis on linguistic knowledge, such as knowledge about grammar and text structure. This approach, therefore, emphasizes the importance of a recursive procedure of writing. There are different views on the stages that writers go through, but a typical model identifies four stages: pre-writing; composing/drafting; revising and editing (Tribble 1996).

The pre-writing activity involves introducing techniques that help the students choose and engage in a topic. That is, a typical pre-writing activity in the process approach is to brainstorm on the topic. At the next step students select and structure the result of brainstorming session. This would result in multiple drafts of the task. After discussion and feedback, the learners revise or proof-read the task. In such a writing process, the central elements are the writer, the content and the purpose. The teacher only facilitates the learners' writings, encouraging their potential. The process approach is thus learner-centered. In short, process approaches are identical to task-based learning where learners are given freedom within the task, concentrating on the "ways" the task is accomplished rather than on the product (the finished text). Taking into account the degree of effectiveness of this approach, linguists and methodologists express their critical views on the approach. For instance, it is noted that the process approach seems to narrowly focus on the skills and process of writing in the classroom itself and, as a result, fails to take into account the social and cultural aspects that have an impact on different kinds of writing (Atkinson 2003:49-63). As a result of such contradictions a new movement, the so-called genre movement, started.

The genre approach considers writing as a social and cultural practice. In some ways, the genre approach is considered to be an extension of the product approach as, 
on the one hand, it focuses on the linguistic aspect of the writing, and, on the other hand, it emphasizes the social context in which the writing is produced. It has been stated that we have a range of different kinds of writing, such as letters, research articles, reports linked with different situations (Flowerdew 1993:307). And, as Paltridge (2001:73-90) claims, the genre approach to teaching writing involves the teaching of a particular genre to students who need it for later social communication. In other words, the focus is on the genre approach to teaching writing as a means of achieving communicative success. The focus should first of all be on the language and discourse features of a particular text. Besides learning about the structure and language features of various text types, the genre-based approach also teaches students to be aware of a number of factors such as the audience, the purpose of writing, the context of writing. Emphasis is placed on how a particular genre will accomplish certain functions or goals. In addition, within the frames of the genre-based approach, the idea that different variations of language are used in different sociocultural contexts and in certain social environments or spheres is promoted. The use of wrong register will not sound appropriate in a certain situation and the goal of the communication will not be achieved. In this process the teacher takes the role of a facilitator until the learners gain autonomy. Considering this approach very important, however, we cannot but admit that, like other approaches, the genre approach has also seen criticism.

Paltridge (2001) mentions that the genre approach combines both the knowledge of the text and a number of social and cultural peculiarities. Comprehension and specification of either is a difficult job for the students. It is also noted that by teaching a particular genre, the teachers are, in fact, not helping the learners (Caudery 1998:1-5). The approach may not require the students to express their own ideas, it may depend on whether the teacher is able to find suitable materials as models or not. Our opinion is that the choice of approach to be used will definitely depend on the teachers, the students and the genre of the text.

We have some reservations as to the skill and competence of the teachers who use the communicative approach. The fact is that although the communicative approach has been introduced recently for teaching English, the ESL teachers in the higher educational institutions in our country are not yet trained properly in the new approach. In Armenia the teachers are still more prone to practise the old grammar translation method. In most cases the teachers' feedback is based on grammatical and lexical errors instead of meaning-oriented explanation. Our English teachers at school or university level still follow the product approach in the writing classes.

The importance of product-based approach cannot be under-estimated or neglected fully as it highlights the learner's final work. However, the process-based approach also needs careful consideration as it highlights the procedure of the text production. That is, the question "What is produced?" can be substituted by "How is it produced?" As noted by Caudery (1995:1-12), TESL has a habit to embrace teaching methodologies with 
fervor, and then, as a few cracks begin to show and it seems that the new teaching approach, which rejects the previous approaches with equal vigor, will not solve every classroom problem. However, numerous studies and practice have shown that the synthesis of the product, the process and the genre approaches will bring to the best results. As Batstone suggests (1994:224-236), we need to mix "the careful control of language for learner (as in product)", and the creative use of language by the learner (as in process)." And while the genre-based approach focuses on the language used in a particular text, it will be necessary to include the processes by which writers produce a text.

\section{Conclusion}

Implementing only one of the approaches in the writing process in the classroom can be unfruitful. On the one hand, the usefulness of the writing process (pre-writing, drafting, revising, etc.) cannot be replaced entirely by the genre approach as the process writing emphasizes the communicative approach and meaning is considered to be more important than the final product. On the other hand, the genre-based approach is useful in the classroom as it teaches the students how to write different types of text for different purposes. The use of this approach will enable the students to differentiate their writings according to various situations and functions which is an essential life skill in the long run through the whole life. By implementing the genre-based approach the students learn about syntax, grammar and vocabulary through the language features of various text types, while the process approach enables them to learn about different genres and discourses. However, the priority of this or that approach does not suggest abandoning the other approaches to writing, but puts forward the demand for complementing one another rather than opposing. Thus a synthesis of the product, the process and the genre approaches to writing will be the best approach to meet the needs of our ESL students in higher education.

\section{References:}

1. Atkinson, D. (2003) Writing and Culture in the Post-Process Era. // Journal of Second Language Writing, 12, pp. 49- 63.

2. Badger, R. and White, G. (2000) A Process, Genre Approach to Teaching Writing. // ELT Journal, 54(2), pp. 153- 160.

3. Batstone, R. (1994) Product and Process: Grammar in the Second Language Classroom. // Grammar and the Language Teacher. // Ed. by M. Bygate, A. Tonkyn and F. Williams. New York: Prentice Hall, pp. 224- 236.

4. Caudery, T. (1995) What does the Process Approach Mean to Practising Teacher of Second Language Writing Skill? // Teaching English as a Second or Foreign Language 1(2), pp. 1-12. 
5. Caudery, T. (1998) Increasing Students Awareness of Genre through Text Transformation Exercises: An Old Classroom Activity Revised. TESL-EJ. 3.3. A2.

6. Flowerdew, J. (1993) An Educational or Process Approach to the Teaching of Professional Genres. // ELT Journal 47/4, pp. 305- 316.

7. Flowerdew, L. (2000) Using a Genre-based Framework to Teach Organizational Structure in Academic Writing. // ELT Journal 54(4), pp. 369- 378.

8. Flower, L. and Hayes, J. (1981) A Cognition Process Theory of Writing. // College Composition and Communication, pp. 365- 387.

9. Paltridge, B. (2001) Genre, Text Type and English for Academic Purposes (EAP). // Genre in the Classroom. / Ed. by A.M. John. Mahwah: Erlbaum.

10. Prodromou, L. (1995) The Backwash Effect: From Testing to Teaching. // English Language Teaching Journal, 21(1), pp. 1-25.

11. Silva, T. (1990) Second Language Composition Instruction: Issues and direction in ESL. // Second Language Writing: Research Insights for the Classroom. / Ed. by B. Kroll. New York: Cambridge University Press, pp. 1-24.

12. Tribble, C. (1996) Writing. Oxford: OUP.

\section{Qpuulnp lunuph nıunıgưua

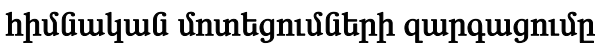

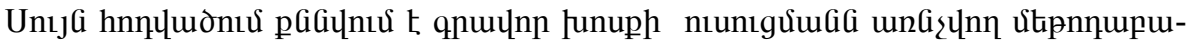

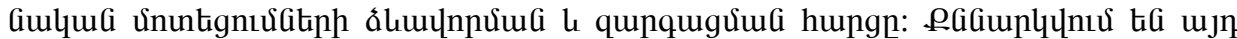

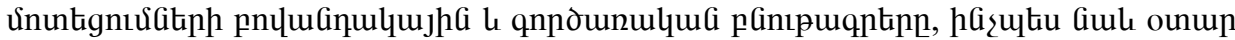

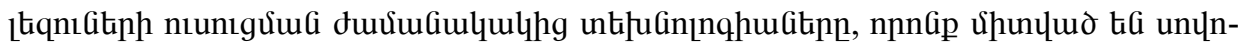

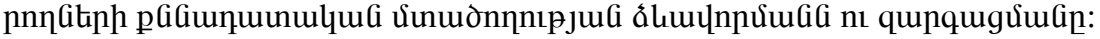

\section{Развитие основных подходов к обучению письменной речи}

В статье рассматривается процесс развития основных методологических подходов к обучению письменной речи, с учетом их содержательных и функциональных характеристик, а также современных технологий обучения иностранным языкам. В итоге развивается критическое мышление студентов, которое является одним из важнейших умений современных учащихся. 